\title{
Quo Vadis Sustainable Military Operations? ${ }^{1}$
}

\author{
Mihály NYITRAI ${ }^{2}$
}

"Sustainability is not a distinct program or initiative within the Army; it is an organizing principle being instilled in everything the Army does to support its mission, including planning, training, equipping, and operations." [1]

Nowadays a well-prepared army must be able not just to rapidly deploy and fight with success but also to sustain itself for a certain period in a challenging environment. For this reason, there is no question that sustainability plays a crucial role in military operations. In addition to sustainability, there are other aspects, like reducing costs and environmental protection, which are associated as well with military activities accompanying the technology development. Sustainable development seems to be a magic expression and stands at the head of the most interesting and researched questions of all societies and organizations of science, and the army is not an exception to this tendency. The high energy consumption of modern military technology and equipment is widely known. Energy for the equipment, water for the personnel, and for both waste management. This paper examines how these ambitions, energy security and sustainability take shape in military operations.

Keywords: sustainability, military operations, energy security, environment, operational logistics

\section{Introduction}

Since the end of the Cold War the world has changed a lot. This statement concerns not only ever-changing nature and human society but military operations as well. In addition, because of some specific requirements, nowadays a soldier and his equipment have more capabilities than they had many decades ago, making today's army more ready and resilient. For example, a soldier can provide power resupply for his battery load giving it 72-hour endurance while on the move or to his mounted platforms to which have been added protection and command ${ }^{3}$ capabilities. Despite their advanced technology, these capability changes demand more energy $^{4}$ or at least an increased efficiency in the use. Miniaturization or a combination of these capabilities into a single device offers only one option to reduce the power demands, other ways could be opened up by using a new type of energy, the main characteristic of which is renewability. [1] So, what actually are the main drivers for these changes and what do they

\footnotetext{
1 „The work was created in commission of the National University of Public Service under the priority project KÖFOP-2.1.2-VEKOP-15-2016-00001 titled “Public Service Development Establishing Good Governance” in the Ludovika Research Group Program.”

2 Practical instructor, National University of Public Service, Faculty of Military Science and Officer Training; e-mail: nyitrai.mihaly@uni-nke.hu

e.g. Joint Tactical Radio System

4 Fuel, electricity, etc.
} 
bring for the actual military operations? There are driving factors: environmental protection ${ }^{5}$ with climate change in its background and the limited access to natural resources.

In 1987, the idea of Sustainable Development (SD) was born, defined by the Brundtland Commission. [2] The thought behind this notion was the recognition that resources available for mankind's development are not without end. According to the definition of sustainable development "the needs of the present must be met without compromising the ability of future generations to meet their own needs.” [3] The Brundtland Report ${ }^{6}$ meant a start for a new era of a socially and environmentally acceptable, sustainable economic growth. [2] The report had and continues to have deep long-term impact on our everyday life including military operations. Governments and international organizations started to establish different goals, build up widespread programs on energy security ${ }^{7}$ and sustainability. Regarding energy security ambitions usually they are pursuing either to reduce the use of petroleum or to increase the consumption rate from renewable sources, ${ }^{8}$ which are first on the list of alternative energy. ${ }^{9}$

The energy hunger of modern military technology and equipment is widely known. Energy for the equipment, water for the personnel, and waste management for both. This paper in the next chapters examines, how United Nations' ambitions for energy security and sustainability take shape in military operations.

\section{Operational Energy and Sustainability}

During slightly longer military operations, it becomes clear quickly that being ready, effective and resilient is not so easy to achieve and maintain. Long supply chains are costly and jeopardize the army's ability to complete its missions, in which a unit's endurance, flexibility and freedom of action are highly appreciated. The army is one of the biggest fuel consumers around the world and its reliance on fuel deepens its operational vulnerability, which stems from operating with platforms and systems that require assured access to large amounts of fuel. Recent experiences in Iraq and Afghanistan proved that the delivery of fuels were often costly both in terms of casualties and finances. Afghanistan not only lacks proper infrastructure and has challenging geography, but due to increased roadside bomb attacks, it is a dangerous country, too. As a landlocked country, the fuel is transported by road, from

5 Environmental protection is not a subject of this paper, yet a main theme, in military terms, is the reduction of operational footprint on the environment by incorporating Life Cycle Management (LCM) in defence procurement, treating end-of-life material and cutting emission of Greenhouse Gases (GHG). By making decisions affecting the environment, the military contingencies and the army itself have the same responsibility to the population and the nation to protect and preserve their environmental resources as the civil sector.

6 “Our Common Future”.

$7 \quad$ Energy Security: "Having assured access to reliable supplies of energy and the ability to protect and deliver sufficient energy to meet mission essential requirements.” [31: para 2924 (3)(A)]

$8 \quad$ It is only a matter of time before oil reserves run out, therefore, we need to find other energy supplies than fossil fuels. It should be mentioned here that according to some opinions the decreasing level of common energy supplies like fossil fuels in the future generates additional tensions, conflicts over the remaining resources, which implicates more military involvements with a higher rate of energy (fuel) consumption. So the whole process could turn into a self-reinforcing loop if we do not pay attention.

9 Another option for alternative energy source provision could be the development of hydraulic fracking for recovering gas and oil from shale rock. This kind of energy source is already remapping the economy and energy sector. 
Karachi (Pakistan), where the fuel tankers for the US troops arrive to the storage locations in Afghanistan. The military transport distributed this fuel to forward operating bases through long lines of logistics. ${ }^{10}$ [5] According to a 2009 report, in Afghanistan US forces suffered one casualty for every 24 fuel resupply convoys, on this basis 170 US service members were killed or wounded in action securing fuel convoys in 2007 alone. ${ }^{11}$ Plus, transporting that fuel miles into battlefields along risky and dangerous routes raised the cost of a $\$ 1.04$ gallon up to $\$ 400$ or even more. ${ }^{12}$ [5] Deloitte ${ }^{13}$ conducted a study of energy use in wartime from World War II through the current wars on the Middle East, and found that there has been a 175\% increase in gallons of fuel consumed per U.S. soldier per day since the Vietnam conflict, which means an average annual increase of $2.6 \%$ in the last 40 years and with an expected $1.5 \%$ annual growth rate through $2017 .{ }^{14}$ [7: Sec1 1] Therefore, it was no wonder that new operational energy and technologies ${ }^{15}$ have begun to take shape on the battlefields.

This new type of energy used during military activities, regardless of its nature, started to be called “operational.” This operational energy increases the troops' endurance to operate on the field and cuts the number of casualties by reducing the risk originated from moving fuel. [8] But different army components (Land, Navy, Air Force, Marine Corps) require different approaches to operational energy, inasmuch as they are facing different operational challenges. Just for common and broader understanding, each form and type of energy (not only the new ones) used in military operations is called "operational.” Of course, the really new operational energy has a determinant characteristic feature of renewability, but each of them-regardless of their nature-must adapt the principles of high effectiveness and efficiency. For this reason, only those forms and types of energy could be used for military purpose, which respect these principles. Having higher effectiveness or efficiency like the Improved Turbine Engine means less consumption, fewer resupply convoys, less risk, less cost and fewer casualties with improved military capability. ${ }^{16}$ But energy efficiency does not apply just to deployed operations. "We train like we fight, we fight like we train" is the main message. For this reason, it is important to have a closer look, how different world organizations (UN, NATO, EU) and their determinant member states with powerful and energy dependent economies regard the problem of energy security and sustainability.

10 For many remote locations, the fuel supplies must be provided by air (in bladders carried by helicopters), which makes this way of supply even more expensive.

11 It is estimated that 3,000 US soldiers were killed or wounded in attacks on fuel and water convoys in Iraq and Afghanistan between 2003 and 2007.

12 For many Forward Operating Bases (FOBs) the fuel could have been provided by helicopters, which is the most expensive option for supply.

13 "Deloitte" is a brand under which dedicated professionals in independent firms throughout the world collaborate to provide, among the other things, risk management.

14 According to this study, the main reasons for this increase of fuel consumption were increased technological mechanization, the expeditionary nature of conflict and the rugged terrain.

15 This technological advancement usually meant mainly solar cells, but it also pointed to improved engine efficiency, like Improved Turbine Engine (ITE) in Blackhawk and Apache helicopters. The former T700 helicopter engine was developed with 1960s technology and periodically upgraded. But despite all upgrades by 2003, the potential improvements had already been maximized and a new design was necessary to improve the engine's capabilities. The new ITE engine of the same or less weight expands operational range with increased payload and altitude through significant operational energy savings.

16 Endurance, readiness, unit autonomy, resilience. 


\section{United Nations: Greening the Blue Helmets}

On 5 June, 2007, UN Secretary General Ban Ki-moon called on all UN related organizations to "go green and become climate neutral." In October 2007, at the meeting of the UN System Chief Executives Board for Coordination the Executive Heads of UN agencies, funds and programs agreed to estimate the UN GHG emission consistent with international standards and undertake efforts to reduce the emissions. "Greening the Blue" is an official UN campaign to achieve a more sustainable United Nations. [9]

The Greenhouse Gas inventory of UN peacekeeping operations, which rely almost exclusively on petrol and diesel fuel for generators, and the 17,000 vehicle fleet as well as jet A1 fuel for the $257 \mathrm{UN}$ aircraft ${ }^{17}$ found that they contribute $56 \%$ of the UN system's total climate footprint of approximately 1.75 million tons of $\mathrm{CO} 2$ equivalent per year. So, the major source of UN GHG emission is the significant fuel consumption, ${ }^{18}$ creating a substantial cost as well. ${ }^{19}$ In converting this GHG emission per UN personnel per year, the most interesting finding was that the UN missions behave like people living in developed countries and greatly surpass the host country's GHG footprint per capita per year.

Table 1. Emission Inventory for 20 peacekeeping missions: 972,304 tons $\mathrm{CO}_{2}$ equivalent (2008). [10: 29]

\begin{tabular}{|l|c|}
\hline Source of emissions & Percentage \\
\hline Air travel (troop rotation, UN air fleet and commercial) & $46 \%$ \\
\hline Power generation & $26 \%$ \\
\hline Road vehicles & $15 \%$ \\
\hline Refrigeration/air conditioning & $9 \%$ \\
\hline Purchased electricity & $4 \%$ \\
\hline Other emissions & $<1 \%$ \\
\hline
\end{tabular}

Inasmuch as UN military operations are set up in technologically less developed countries and regions not having a proper power grid, something had to be done. For example, the UN logistics base in Brindisi is piloting around forty electric cars, forklifts and reach trucks. Due to the "Greening the Blue" program the UN vehicles either are to be purchased according to fuel efficiency standards or electric cars, forklifts are to be used. ${ }^{20}$

Another way to reduce fuel consumption is to operate CarLog systems monitoring fuel consumption and speeds. A committee monitors energy use and informs staff of wasteful practices (idling times of vehicles, heating and cooling units set not at efficient temperatures, etc.).

17 Troop deployment, rotations, road transport, power generation, etc.

18 On the basis of a US Army Environmental Policy Institute (USAEPI) study which found that for every one litre of fuel used in remote bases, more than 6 litres of fuel were used to transport it. Adding to this finding, $70 \%$ of all tonnage shipped to these remote bases was fuel.

19 The costs of fuel resupply can be calculated (see later) not only in dollars, but also in lives. So decreasing fuel consumption with raising efficiency has the potential to lower casualty rates.

20 UNIFIL-United Nations Interim Force in Lebanon; actually uses 10 electric cars in UNIFIL headquarters in Naquora. 
This CarLog system ${ }^{21}$ in Timor-Leste ${ }^{22}$ has led to a 22\% drop in UNMIT vehicle idling times and 15\% drop in energy consumption over 12 months. ${ }^{23}$ [10: 29]

In the pursuit of ambitions to reduce its own GHG emission and help the regions of UN peacekeeping operations meet their energy needs, the UN has also other projects to implement. In this area of renewable energy, the UN has laid down a way forward. One of the latest outcomes in the field of using renewable energy for UN military installation and operations is a solar farm in Naqoura (Lebanon), the solar energy of which powers a UNIFIL base. [11] According to the UN Environment Programme (UNEP)—which issued the Global Trends in Renewable Energy Investment 2016 publication-it noted the annual global investment (265,8 Mrd\$) in new renewable capacity was more than double the estimated investments (130 Mrd\$) in coal and gas power stations in 2015. [12] As comparative data from UN peacekeeping operations show, the capital investment for some renewable technologies could be recovered in up to 5 years. [10: 31]

Not only in Africa but all over the world water is a key issue. For planning purposes, the UN Department of Field Support estimates water use at 84 litres per person per day. ${ }^{24}$ Over a course of a year a peacekeeping operation of 15,000 personnel would consume 459,900,000 litres. ${ }^{25}$ [10: 26] For this reason it is vital for a mission to find a feasible solution for water supply. Water quality, of course, is an important issue solved usually by the use of UN-contracted water treatment plants. ${ }^{26}$ But there are other solutions for improved water use, like setting up rainwater tanks. The use of rainwater tanks is the less expensive way to access the water. Although these rainwater tanks are relatively low-cost tools, they are not used at most UN missions. One of the exceptions is United Nations Mission in Sudan (UNMIS). The mission has installed 5,000 and 10,000 litre rainwater collection tanks to supply non-potable uses (toilets, laundry, washing equipment, irrigation, dust suppression, etc.). But rainwater combining with careful collection and filtration can be used for potable purposes also. [10: 26] it is quite a new image to see wastewater treatment units in UN peacekeeping missions, and used to reduce demands for external water resources. Nevertheless, this is the case for African Union/United Nations Hybrid operation in Darfur (UNAMID), ${ }^{27}$ which operates 106 of these units, each of them capable of treating the grey and black water generated by 200 people. Reducing annual freshwater use by up to $40 \%$, the final product is satisfactory for activities with limited human contact such as toilets, fire-fighting and irrigation. [10: 37]

21 Plus the application of awareness stickers to vehicle windscreens.

22 UNMIT-United Nations Integrated Mission in Timor-Leste.

${ }_{23}$ A common rule of thumb says that 1 degree of reduced artificial heating/cooling demand translates to $5 \%$ savings in energy use for heating/cooling the building. Usage of 50,000 litres equates to an annual savings of USD 360,000 .

24 This amount of 84 litres can be compared to the UNHCR recommendation for water in refugee situations of 15 litres per person per day, and an absolute survival minimum of 7 litres.

25 In such a way, it can be seen that a mission can easily exacerbate local water scarcity using ground or surface water at rates beyond the ability of the natural system to recharge.

26 In case of having own UN water infrastructure, at the closure of a mission, the infrastructure can be handed over to local communities.

27 UNAMID is a mission of some 20,000 uniformed personnel. High temperatures ensure a high demand for potable water for everybody including the local community, which might see the peacekeepers as resource competitors. The local water supply is scarce because of inadequate groundwater recharge, low annual rainfall and competing demands from local agricultural communities. So everything is given to establish such wastewater treatment units. 
One of the Millennium Development Goals ${ }^{28}$ is to ensure environmental sustainability. [14] In the year 2015, ${ }^{29}$ UN Member States adopted a new sustainable development agenda Transforming our world: The 2030 Agenda for Sustainable Development ${ }^{30}$ with 17 Sustainable Development Goals and 169 targets. [15] Among these 17 goals are to ensure availability and sustainable management of water and access to affordable, reliable, sustainable, modern energy. [16] So the security concerns need to be embedded in sustainable development. Currently, the Department of Peacekeeping Operations (DPKO) runs 16 peacekeeping operations consisting of almost 100,000 military personnel that needs around 2.2 million gallons of fresh water per day. It is a huge amount of water to provide. Of course, nowadays, several water efficient technologies exist to reduce consumption, but sometimes they do not even require any investment, they simply make personnel pay attention to water use. It was found that token operated showers UN Mission in South Sudan (UNMISS) can half the water consumption during a 10 -minute shower. ${ }^{31}$ Very low-cost rainwater tanks are installed either for non-potable water use activities or combined with proper filtration and careful collection to supply potable use. [10: 28] It must be added that sometimes wastewater investments are just one side of the coin. The other one is the mission staff's education about the proper use to avoid having water-borne diseases and to overcome certain cultural barriers.

In 2012, at the Rio+20 Conference Member States requested the UN to improve the management of facilities and operations by taking into account sustainable development practices. [32: para 96] In September 2014, it was stated by the Secretary General that the UN will be climate neutral by 2020. With the participation of DPKO and the Department of Field Support (DFS) there is a UN-wide working group on sustainability management.

\section{NATO: Framework for Green Defence}

In February 2014, the NATO Defence Policy and Planning Committee agreed to the NATO Framework for Green Defence, which provides a basis for Member States to cooperate on green solutions for defence. Later, in 2016 the NATO Member States in the Warsaw Summit Declaration stated also that they would further improve the energy efficiency of their forces through establishing common standards, reducing dependence on fossil fuels and demonstrating energy-efficient solutions. [17] These steps were necessary because till that the development of green policies and strategies had primarily been a national concern. For the NATO Green Defence Framework there is no new imperative than those mentioned above for UN operations. ${ }^{32}$

Fuel consumption before the Afghanistan (2001) and Iraq (2003) operations was not considered a distinct operational problem. When these operations continued, it became clear that the

28 As a side note, according to the World Bank and the Office of Disarmament Affairs (ODA), only about 5\% of the amount of money spent on the defence sector ( $\$ 4.7$ billion a day or $\$ 249$ per person) would be needed each year to achieve the Millennium Development Goals by 2015.

2925 September, 2015.

30 The Agenda has five pillars (5P): Peace, People, Planet, Prosperity and Partnerships.

31 Because of severe climate conditions, the mission is a UN "spearhead" of water efficient technologies. Besides token operated showers, waterless urinals are pilot tested in UNMISS through funding from the Swedish Government. The mission in UNAMID operates wastewater treatment plants to supply non-potable uses.

32 Greenhouse gas emissions, fuel costs with hidden casualty costs, scarce local water supplies, etc. 
provision of fuel used to power ground and air vehicles with advanced weapons, to surveillance and protection systems was a real challenge for logistic service personnel and cost a lot in dollars for taxpayers ${ }^{33}$ and in lives for troops on the battlefields. ${ }^{34}$ [8] For this reason, the development and use of alternative energy with increased efficiency can directly reduce wartime casualties. ${ }^{35}$ In order to reduce casualty factors, the alliance should reduce troops' needs for resupply (fuel and water) convoys, which means increased energy efficiency, renewable energy use and onsite water production. Referring to the findings of the Sustain the Mission Project: Casualty Factors for Fuel and Water Resupply Convoys report by the US Army Environmental Policy Institute, a $10 \%$ reduction in fuel consumption over a five-year period could lead to a reduction of 35 fuel-related resupply casualties over the same period. [19] While it is not a question that energy saving can also save lives in the front line, ${ }^{36}$ the military commanders should always find a healthy balance between vulnerability and supply efficiency. But next to casualties, there might be other reasons to move away (at least partially and to some extent) from fossil fuels, these are the likely disruptions of supply chains due to weather and possible political fallout. For example, in 2011, after a US airstrike killed 24 Pakistani soldiers, the country shut down the NATO supply routes for over a year. The closure of supply routes forced NATO to find alternative methods of moving supplies, 70\% of which were fuel into Afghanistan. The fuel trucks already in the supply line were vulnerable. Up to 34 fuel and goods trucks - supplying NATO troops in Afghanistan and parking on a NATO temporary trucking terminal after the supply line was shut down — were destroyed in a rocket attack in Quetta, Pakistan. [20]

While the operations in Afghanistan and Iraq were continuing with increased financial and logistics burden, ${ }^{37}$ the defence budgets of the NATO Member States started shrinking. This process encouraged the stakeholders to revise their energy consumption and find solutions for the shrinking defence budgetary problems. The solution found was renewable (green) energy itself. So, the defence expenditures started being associated with green solutions, while the latter's research and development required centralization and change of information on lessons learned. The NATO Green Defence concept in overall terms concerns military operations, defence expenditures, energy security and climate change.

33 Or to free up military resources for other missions.

34 Around $80 \%$ of US military casualties in Afghanistan are due to improvised explosive devices, many of which are placed in the path of supply convoys.

35 For example, the casualty factor for fuel resupplies in Afghanistan is 0.042, which means basically one casualty for every 24 fuel resupply convoys.

36 Lighter weapon systems mean more fuel savings, less resupply convoys and greater range with increased operational effectiveness but this could impose risk on troops by providing less capability to protect.

37 On 28 November, 2011, after a US airstrike killed 24 Pakistani border troops. In retaliation Pakistan closed its borders for seven months to supplies, $70 \%$ of which were fuel. During the closure, the US was forced to use more costly and lengthy routes through the former Soviet Union. As an additional consequence, in the next month up to 34 NATO fuel trucks were destroyed in a rocket attack on a NATO trucking terminal in Quetta. That time around 130,000 US-led international troops were fighting in Afghanistan. 
Table 2. The Green Defence concept, the associated security challenges, general and specific solutions. [8]

\begin{tabular}{|c|c|c|c|}
\hline Concept & Security challenges & General solutions & Specific solutions \\
\hline $\begin{array}{l}\text { Green } \\
\text { Defence }\end{array}$ & $\begin{array}{ll}- & \text { military operations } \\
- & \text { defence } \\
- & \text { expenditures } \\
- & \text { energy security } \\
- & \text { climate change }\end{array}$ & $\begin{aligned}- & \text { reduce energy } \\
& \text { demand } \\
- & \text { increase and } \\
& \text { diversify energy } \\
& \text { supply } \\
- & \text { adjust force } \\
& \text { structure and } \\
& \text { defence planning }\end{aligned}$ & $\begin{array}{l}\text { New green technologies: } \\
-\quad \text { more efficient combustion } \\
\quad \text { engines } \\
-\quad \text { solar panels } \\
\text { Green strategies and manage- } \\
\quad \text { ment systems: } \\
-\quad \text { green strategy for defence } \\
-\quad \text { key performance parameters }\end{array}$ \\
\hline
\end{tabular}

Regarding the security challenges in Table 2, it is quite interesting to mention the Net Zero Initiative of the US Army, which was announced in October 2010. The objective of this program is to make military installations net zero in terms of energy, water and solid waste. For energy, this means producing as much renewable energy on-site as they use in a year. For water, this means limitations for the consumption of fresh water resources and returning water to the same watershed, so as not to deplete the groundwater and surface water resources. For waste, this means that the military installation reduces, reuses and recovers waste streams, converting them to valuable, usable resources, disposing of no solid waste in landfills. The army invested more than $\$ 100$ million of appropriated funds in energy efficiency and water conservation projects in 2013 - an investment expected to save 500 billion British Thermal Unit (BTU) per year starting from 2014. [1]

In NATO, to address the challenge of energy security, Lithuania as a Framework Nation established $^{38}$ the NATO Energy Security Centre of Excellence ${ }^{39}$ (ENSEC COE). One of the basic missions of NATO ENSEC COE is to provide energy security related solutions for the development of environmentally friendly and efficient military capabilities in support of NATO operations and forces through Smart Defence ${ }^{40}$ and Energy. ${ }^{41}$ For example, in June 2015, NATO ENSEC COE conducted the Capable Logistician 2015 exercise in Hungary. The exercise took place at Bakony Combat Training Centre near Veszprem with the support of NATO’s Science for Peace and Security Programme. The exercise tested how the equipment interacts when using different energy-efficient technologies. The featured scenarios consisted of responding to power cuts, generators breaking down and diesel/water contamination. The technologies which were applied included inter alia, micro grids to improve a camps' energy management, renewable energy sources, such as wind and solar power, low-energy technologies for water purification, small portable fuel cells for NATO soldiers and LED lights. [23]

NATO places strong emphasis on scientific work and education as well. NATO's annual Energy Security Roundtable brings together experts from academia, international organiza-

38 Created on 10 July 2012, and credited on 12 October, 2012.

39 The organization is coordinated by NATO Allied Command Transformation in Norfolk.

40 NATO Smart Defence is a cooperative way of generating modern defence capabilities that NATO needs in a more cost-efficient, effective and coherent manner. Through this culture of cooperation, Member States are encouraged to work together to develop and maintain military capabilities to undertake core tasks agreed to in NATO's Strategic Concept.

41 NATO Smart Energy is a program to improve the energy efficiency of allied armed forces through a wide range of means, such as the increased use of renewable energy and better energy management. 
tions and the private sector to discuss global energy developments and their security implications. In 2015 NATO conducted its first ever Energy Security Strategic Awareness Course at the NATO School in Oberammergau, with participants from allied and partner countries.

\section{European Union: Military Green and Energy Management}

At the Gothenburg Summit in June 2001, EU leaders launched the first EU Sustainable Development Strategy (SDS). The Strategy set objectives for seven challenges for the period until 2010: climate change and clean energy; sustainable transport; sustainable consumption and production; conservation and management of natural resources, public health, social inclusion, demography and migration; global poverty and sustainable development challenges. In July 2009, the European Commission adopted the 2009 Review of the European Union Strategy for Sustainable Development, [24: 2] according to which Sustainable Development was still set out as an overarching, long-term goal for the EU under the Lisbon Treaty. The Commission's communication-Rio +20: Towards the green economy and better governance $^{42}$ - from 2011 on also included sustainable development. The communication refers to the Europe 2020 Strategy, [25] launched in March 2010, and aiming at achieving "smart, sustainable and inclusive growth" as an effective tool for delivering sustainable development in the EU. The Strategy sets three key targets:

1. $20 \%$ cut in greenhouse gas emissions (from 1990 levels);

2. $20 \%$ of EU energy from renewables;

3. $20 \%$ improvement in energy efficiency.

The European Defence Agency (EDA) was established ${ }^{43}$ to support the Member States and the Council in their effort to improve the European defence capabilities of the EU Member States in the field of crisis management and to foster cooperation to become more cost efficient. "Military Green" 44 is an initiative which is building on legislation and EU directives and an effort through the Agency ${ }^{45}$ to achieve an environmentally acceptable defence. The initiative is aiming at establishing principles and responsibilities to meet the requirements of Environmental Protection during EU-led military operations. as the EU is committed to sustainable development and security, Military Green promotes good environmental management during military operations with reduced logistical burden on the forces. in 2014, next to "Military Green” the European Union Military Staff (EUMS) developed its European Union Military Concept on Environmental Protection and Energy Efficiency for EU-led military operations to provide strategic guidance for the consideration of environmental protection and energy efficiency. [26] The concept addresses not only energy efficiency but also the use of renewable energies during military operations. [27] For example, in 2015 energy

42 In 1992, the Sustainable Development Strategy was approved by more than 170 state representatives at the UN World Summit in Rio de Janeiro. Twenty years later in 2012, a UN Conference marked the $20^{\text {th }}$ anniversary of this 1992 UN Conference on Environment and Development. The expression Rio+20 highlights the place and time elapsed between the two conferences. The objective of this 2012 Conference was to manifest a renewed political commitment to sustainable development, to assess the progress and the remaining gaps and to address new and emerging challenges.

$43 \quad 12$ July 2004.

$44 \quad$ Launched in 2011.

45 Since 2014 there is an EDA working group (Energy and Environment) addressing energy issues for military activities. 
management equipment ${ }^{46}$ was installed for a test period of twelve weeks at camp Koulikoro (EU Training Mission in Mali — EUTM Mali) ${ }^{47}$ The equipment is part of EDA's Smart Camp Technical Demonstrator (SECTD) project, which analyses the benefits of integrating new technologies into traditional power grid for deployed camps. [28] The SECTD is part of those three EDA initiatives, whose objectives are to promote moving towards environmentally more sustainable military operations. The project has three main objectives:

1. to test and verify the efficiency of combat suitable solar photovoltaic panels in specific climatic conditions;

2. to test "demand management" technology and its impact on inhabitants;

3. to collect data for planning support tools.

Smart Blue Water Camps is the second EDA initiative focusing on water management techniques and technology interventions to reduce water consumption for fixed military installations. The third EDA initiative is closely connected to the use of the Energy Management Systems (EnMS). Experience shows that efficiency of renewables greatly depends on the EnMS being employed or not. A comprehensive EnMS training course helps EU Member States to apply a system-based approach to energy management. [29] The basis of this approach is shown in Figure 1.

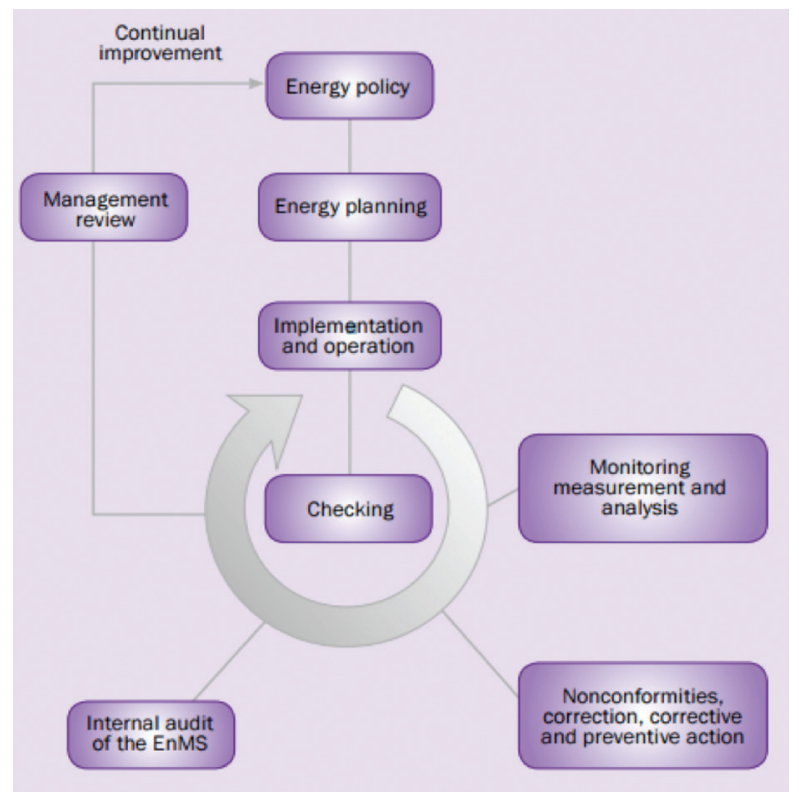

Figure 1. Energy Management System model. [30: C1]

46 The systems include fixed solar photovoltaic panels (16KWp), flexible soldier portable solar photovoltaic panels and monitoring-metering equipment for water and electricity.

47 The test equipment integrated into the power generation grid for the camp supplied $33 \%$ of the test building's electrical load and allowed all rooms to have functioning air-conditioning when no external supply was available. 


\section{Conclusions}

Energy availability is an essential part of operations and of the logistical footprint. From a historical operational view, there is a marked change in the approach towards decreasing the use of energy and other natural resources. This U-turn demonstrates that resources are no longer constraints of operational effectiveness, but on the contrary, they are rather mission enablers. Nowadays the forces must move rapidly and manifest being self-sustaining at least for 72 hours in a challenging environment. Implementation of these requirements cannot be done without mastering energy security and sustainability, as both play a crucial role in the success of military operations. Energy security means having assured access to reliable supplies of energy and the ability to deliver sufficient energy to meet operational needs. But the available resources have their limits and without making their optimal use with the lowest possible logistics footprint, we cannot reach our goals. So, we need to improve our resource efficiency, expand alternative and renewable energy opportunities. Meanwhile doing so, we should not forget about environmental protection issues and maintaining fair relationships with local communities.

Regarding the complexity of serving energy supplies there are other aspects to be considered. First of all, they are costly in dollars and in lives. Secondly, resupply convoys themselves contribute to environmental damage. Therefore, increased energy efficiency reduces the logistical footprint, costs, environmental damage and saves lives. Since energy efficiency is not satisfactory, we must develop environmentally conscious behaviour and culture as well. This will take long years but the world organizations have already started working on such changes.

\section{References}

[1] US Army: Sustainability Report 2014. RefID: A-D9DAFD3, 2014. www.army.mil/e2/c/ downloads/367149.pdf (Downloaded: 1711 2016).

[2] UN C. o. S. D.: Framing Sustainable Development: The Brundtland Report - 20 Years On. Sustainable Development in Action (2007). www.un.org/esa/sustdev/csd/csd15/media/ backgrounder_brundtland.pdf (Downloaded: 1711 2016).

[3] United Nations: Our Common Future, From One Earth to One World. An Overview by the World Commission on Environment and Development. www.un-documents.net/ourcommon-future.pdf (Downloaded: 1711 2016).

[4] US Army: Energy Security \& Sustainability (ES2) Strategy. RefID: 2-204FF1C, 2015. www. army.mil/e2/c/downloads/394128.pdf (Downloaded: 1711 2016).

[5] TIRON, R.: $\$ 400$ per Gallon Gas to Drive Debate over Cost of War in Afghanistan. http:// thehill.com/homenews/administration/63407-400gallon-gas-another-cost-of-war-inafghanistan- (Downloaded: 1711 2016).

[6] NATO: NATO and Its Partners Become Smarter on Energy. www.nato.int/cps/en/natohq/ news_118657.htm (Downloaded: 1711 2016).

[7] Deloitte LPP: Energy Security. America Best Defense. 2009. www.offiziere.ch/wp-content/ uploads/us_ad_EnergySecurity052010.pdf (Downloaded: 1711 2016).

[8] LARSEN, K. K.: Unfolding Green Defense. Linking Green Technologies and Strategies to Current Security Challenges in Nato and the Nato Member States. 2015. 
[9] United Nations: Greening the Blue. www.greeningtheblue.org/ (Downloaded: 1711 2016).

[10] JENSEN, D., HALLE, S. (Eds.): Greening the Blue Helmets. Environment, Natural Resources and UN Peacekeeping Operations. Stevenage: United Nations Environment Programme, 2012.

[11] United Nations: Solar Energy Powers UN Mission Base in Lebanon. www.unmultimedia. org/photo/detail.jsp?id=516/516761\&key=50\&query=organization:UNIFIL\%20AND\%20 category:\%22Field\%20coverage\%22\&lang=\&sf (Downloaded: 1711 2016).

[12] FS-UNEP C. C.: Global Trends in Renewable Energy Investment. 2016. fs-unep-centre.org/ sites/default/files/publications/globaltrendsinrenewableenergyinvestment2016lowres_0.pdf (Downloaded: 1711 2016).

[13] ARCHER, C., WILLI, A.: Opportunity Costs: Military Spending and the UN's Development Agenda: A View from the International Peace Bureau. 2012. sustainabledevelopment.un.org/ getWSDoc.php?id=3260 (Downloaded: 1711 2016).

[14] United Nations: Millennium Development Goals and Beyond 2015. Goal 7: Ensure Environmental Sustainability. www.un.org/millenniumgoals/environ.shtml (Downloaded: 17 11 2016).

[15] United Nations: Sustainable Development Knowledge Platform. Transforming our world: The 2030 Agenda for Sustainable Development. https://sustainabledevelopment.un.org/ post2015/transformingourworld (Downloaded: 1711 2016).

[16] United Nations General Assembly: Transforming Our World: The 2030 Agenda for Sustainable Development. Annex 2015. www.un.org/ga/search/view_doc.asp?symbol=A/69/ L.85\&Lang=E (Downloaded: 17112016.

[17] NATO: Smart Energy: NATO Documents. www.natolibguides.info/smartenergy/documents (Downloaded: 1711 2016).

[18] KABLE: Casualty Costs of Fuel and Water Resupply Convoys in Afghanistan and Iraq. www.army-technology.com/features/feature77200/ (Downloaded: 1711 2016).

[19] EADY, D. S., SIEGEL, S. B., BELL, S. R., DICKE S. H.: Sustain the Mission Project: Casualty Factors for Fuel and Water Resupply Convoys. Final Technical Report. Fort Belvoir: US Army Environmental Policy Institute, 2009. assets.documentcloud.org/ documents/563651/smp-casualty-cost-factors-final1-09.pdf (Downloaded: 1711 2016).

[20] TIFFEN, A.: Going Green on the Battlefield Saves Lives. 2014. warontherocks.com/2014/05/ going-green-on-the-battlefield-saves-lives/ (Downloaded: 1711 2016).

[21] US Department of Defense: Strategic Sustainability Performance Plan. 2016. www.denix. osd.mil/sustainability/dod-sspp/unassigned/department-of-defense-strategic-sustainabilityperformance-plan-fy-2016/ (Downloaded: 1711 2016).

[22] NATO: Smart Defence. www.nato.int/cps/en/natohq/topics_84268.htm (Downloaded: 1711 2016).

[23] NATO: NATO “Smart Energy” Exercise Gets Underway in Hungary. www.nato.int/cps/en/ natohq/news_120481.htm?selectedLocale=en (Downloaded: 1711 2016).

[24] European Union: Communication from the Commission to the European Parliament, the Council, the European Economic and Social Committee of the Regions. Mainstraiming sustainable development into EU policies: 2009 Review of the European Union Strategy for Sustainable Development. http://eur-lex.europa.eu/legal-content/EN/TXT/ PDF/?uri=CELEX:32009L0028 (Downloaded: 1711 2016). 
[25] European Union: Europe 2020: A European Strategy for Smart, Sustainable and Inclusive. ec.europa.eu/eu2020/pdf/COMPLET\%20EN\%20BARROSO\%20\%20\%20007\%20-\%20 Europe\%202020\%20-\%20EN\%20version.pdf (Downloaded: 1711 2016).

[26] European Union: European Union Military Concept on Environmental Protection and Energy Efficiency for EU-led military operations. blogg.forsvarsmakten.se/miljo/wpcontent/blogs.dir/17/files/2012/09/EU-koncept1.pdf (Downloaded: 1711 2016).

[27] European Union Military Staff: European Union Concept for EU-led Military Operations and Missions. data.consilium.europa.eu/doc/document/ST-17107-2014-INIT/en/pdf (Downloaded: 1711 2016).

[28] EDA: EDA Installs Energy Management Equipment at EUTM Mali Camp. eda.europa.eu/ info-hub/press-centre/latest-news/2015/10/13/eda-installs-energy-management-equipmentat-eutm-mali-camp (Downloaded: 1711 2016).

[29] McMANUS, S.: From Military Green to Mali: How the European Defence Agency Meets Energy Challenges. Engineer Journal, 17 May 2016. www.engineersjournal.ie/2016/05/17/ military-green-european-defence-agency/ (Downloaded: 1711 2016).

[30] Win the energy challenge with ISO 50001. www.iso.org/files/live/sites/isoorg/files/archive/ pdf/en/iso_50001_energy.pdf (Downloaded: 1711 2016).

[31] National Defense Authorization Act for Fiscal Year 2012, Public Law 112-81, December 31, 2011. www.gpo.gov/fdsys/pkg/PLAW-112publ81/pdf/PLAW-112publ81.pdf (Downloaded: 1711 2016).

[32] United Nations: The Future We Want. Rio+20. United Nations Conference on Sustainable Development. Rio de Janeiro, 20-22 June 2012. https://sustainabledevelopment.un.org/ content/documents/733FutureWeWant.pdf (Downloaded: 1711 2016). 